\title{
Walter Struve
}

\section{In Search of "Herr O."}

The name of the German-born Australian writer and broadcaster, Kurt Offenburg (1898-1946), has fallen into obscurity. At the time of his death, he was "well known throughout Australia as a hard-hitting, outspoken, and realistic interpreter of international affairs" (Anon. 1946b); in Germany he may be remembered for thoughtful, probing essays, reviews and a novel (1925a), which the Australian poet and scholar, Christopher Brennan (1870-1932), later translated into English (Offenburg 1934), as well as "a few" of Offenburg's articles and poems (Offenburg 1942c).

A snapshot of Offenburg as a writer in Weimar Germany is captured in a letter he wrote in 1924 to an older colleague, Armin Wegner (1886-1978). There he mentioned three forthcoming books, including a novel, as well as the work for newspapers and journals that was necessary for basic survival. Offenburg described the novel as the tale of a malicious bookseller and publisher. He summed up his own situation with allusions to Balzac and Flaubert: "Rastignac c'est moi."

Offenburg touched upon what he meant by this in a short dialogue, published in the following year, where a writer ("Er") discusses with his female companion ("Sie") how a writer's energies are largely used to produce work (1925c). In an earlier reflection, on intellectuals and the proletariat, Offenburg described the intellectual as a holy stylite for the mercantile-saturated bourgeois; the intellectual, he added, offered cleverness to shine over an empty bourgeois existence (1921:376). He saw hope in the emerging voice of the proletariat, for example "the fantastic loving warmth of a Gerritt Engelke" (1925b:13).

Offenburg himself published some ten books (Struve 2006a:66), the 
last five in Australia. That he was planning more is apparent from an obituary which noted that, "at the time of his death, he was engaged on several books, as well as a collection of his poems" (Anon. 1946a); these, however, appear to have been lost.

His journalism was indeed "hard-hitting, outspoken, and realistic", and a headache for the wartime censors, as can be seen in a broadcast typescript for 30 January 1942. The following lines were to have formed the final paragraph of a commentary on the advancing Japanese army and its threat to Australia (1942a):

Singapore has ceased to be a barrier which protects this country. The Dutch East Indies have found that out already. It may be more palatable to hear from overseas that an invasion of Australia is unlikely: but nearer the truth is the $\mathrm{FACT}^{1}$ - that the final decisions in the Pacific have become not only possible but a reality. We were warned, but it fell on the deaf ears of incurably wishful thinkers.

The journalism revealed considerable sensitivity, as seen on 6 July 1945, when Offenburg returned to the situation Australia found itself in during this "deadly-critical period" of early 1942. Paying tribute to the Australian Prime Minister, John Curtin (1885-1945), who had died on the previous day, Offenburg reminded listeners that the situation had been "dark and desperate." He also reminded them of the qualities in Curtin that had prevailed (1945a):

His political judgement was clear and unerring; his courage great to the point of perfection; and his kindness, as I have reason to know, unselfish and without thought of applause. He was not a man who stood in the marketplace. He was a solitary man, without the facility of back-slapping. What a precious and inestimable gift for politicians!

That same year, Offenburg reprinted an essay from 1928, in which he had set down desperate, heartbreaking reflections on the First World War (1928b). Now it appeared in English translation, with newly added introductory words (1945b:39):

We know that War exists; yet we trust, hope, desire that this modern, mad industrialized form of killing, the hopeless deliverance of living man to the machine, will come one day to an end. 
Sixty-two years after Kurt Offenburg's death, the following article offers four glimpses of him, building on three earlier explorations (Struve 2004, 2006a, 2006b).

\section{Ein Mann, der sich Offenberg oder Offenburg nennt}

On 13 September 1930 the German Consul-General in Batavia, capital of the Dutch East Indies, wrote to the German Foreign Office in Berlin to report on a visitor, "ein Mann, der sich Offenberg oder Offenburg nennt" (Kessler 1930), a man who calls himself Offenberg or Offenburg. Nine days earlier this visitor had dropped in on him unexpectedly and stated that he was a representative of the Frankfurter Zeitung, but showed no identity papers; the visitor had quizzed the Consul-General about the conditions under which Germans in the area were living, their occupations, as well as the general economic situation. The Consul-General had been preoccupied with organizing a farewell for the departing American Consul-General. He suggested that the visitor return for a chat on the following morning and lent him a copy of the Deutsches Jahrbuch für Niederländisch-Indien to look through.

Next day the consulate received a telephone call from the hotel where the visitor was staying and was informed that "Herr O." - as the Consul-General now referred to the visitor - did not have time to come for a chat. Nine days later the borrowed Jahrbuch was returned with thanks, together with a forwarding address in Australia. It was then that the Consul-General wrote the letter in which he expressed misgivings about the German newspaperman who had passed through his patch. "One never knows what such people later put into their articles," the Consul-General wrote, adding that he had heard from others that there may be traveller's tales appearing in "the Frankfurter." To be on the safe side, the Consul-General decided to report this visit. But otherwise, he assured the Foreign Office, the man did not concern him: "im Uebrigen ist mir Herr O. völlig Hekuba..." (Kessler, ibid.)

The Consul-General was Friedrich von Kessler (1875-1933), son of a Prussian officer and himself an officer who had attained the rank of Lieutenant Colonel before joining the Foreign Office in 1920. He 
became German Consul-General in Batavia in 1926 (DJNI 328). At the time of his encounter with Offenburg, Kessler was fifty-five, and Offenburg not yet thirty-two.

Did Kessler's letter to the Foreign Office - an outfit described by an Australian observer in 1936 as resembling a "conservative old clubman" (Bonnell 13) - cause subsequent difficulties for Offenburg? Was the letter grounded in distrust towards the Frankfurter Zeitung, a newspaper that "was always regarded, and indeed regarded itself, as a linch-pin in the German liberal-democratic tradition" (Eksteins 1971:4), and its representatives?

\section{A noted German author, playwright and journalist presently visiting Australia}

Kurt Offenburg arrived in Sydney on 6 October 1930, on the Nieuw Holland, "one of the most graceful liners to operate to Australia before the war" (Plowman 53), and stayed at the Australia Hotel, "the nation's premier grand hotel" (Ramsland 21), where he was welcomed as "a noted German author, playwright and journalist presently visiting Australia" (Anon. 1930). Offenburg, we learn, was planning to write a book on his travels, and possibly a book on Australia, as well as reports for German newspapers.

Offenburg's practice was to observe places through "zig-zag travels" rather than to "merely" read facts and figures (1941:19-20), although he did this too. It gave his work a personal style and integrity. Insights were grounded in direct experience. On the Pacific, for example, he wrote (1941:21):

The old romanticism of the Pacific - as Stevenson, Melville, and even Jack London found it - has disappeared. The new romanticism, which has replaced it, includes trade, investment of capital, spheres of influence and - naval bases. The adventure of yesterday no longer exists. Ten and fifteen thousand ton cargo steamers and twenty-five thousand ton passenger vessels travel with an exactness of a railway time-table. Even distant and out-of-the-way islands are regularly brought into the net of traffic as long as they can yield cargo.

Australian listeners to Offenburg's subsequent radio commentaries 
appreciated his "having been there" (Elkin 72); the University of Sydney's Vice-Chancellor stated that "Offenburg was the only man from whom one learned something" and that "he was very good" (Marks). Back in 1930, he set to work swiftly, visiting various sheep and cattle stations in the Mudgee district, the steelworks in Newcastle, the mining town of Cessnock, and Canberra.

The Australia Hotel had been his base from October to December 1930. Offenburg returned to the hotel in March 1931, again in June 1932, in January 1933, and in February 1934. Between these dates he travelled outside Australia - for "study and writing" (Offenburg 1936) - in New Zealand (December 1930 to March 1931), British Malaya and Ceylon (May to June 1931), Germany (August to December 1931), Hong Kong, Japan and China (January to May 1932), New Zealand (January to March 1933), and Hong Kong (May 1933 to January 1934).

A more complete picture emerges from German sources. On 2 April 1932, for example, the Frankfurter Zeitung wrote to inform the German Foreign Office that it had retained Dr. Kurt Offenburg as its correspondent in Shanghai (BRFZ 1932). Earlier, on 28 November 1931 , the newspaper informed the Foreign Office that it was sending Mr Kurt Offenburg as its special correspondent to the northern war zone in China, then possibly to Japan (VFZ 1931). One trip (November 1932 to January 1933), not listed above, was reported elsewhere: "Dr. Kurt D. Offenburg, a representative of the Frankfurter Zeitung is a passenger by the Nankin, which sails to-day for Yokohama and other Eastern ports" (Anon. 1932).

By 1936, he was naturalized, settled in Sydney, and had begun work with Australia's national broadcaster, the Australian Broadcasting Commission.

\section{Jeder einzelne Mensch eine Welt!}

In the Jewish corner of the old cemetery in Offenburg, close to the Black Forest in the German state of Baden ${ }^{2}$,stands a gravestone bearing the names of Josef Dreifuss (1866-1915) and Rosa Dreifuss, 
née Halle (1873-1916). Underneath their names is a line from Proverbs (20:27) in German translation, "Die Seele des Menschen ist eine Leuchte Gottes": the soul of man is a lamp of God ${ }^{3}$. The death notice for Josef in the Offenburger Tageblatt (19 July 1915) had been signed by "Rosa Dreifuß geb. Halle, und Kinder" and, one year later (29 July 1916), the death notice for Rosa was signed by "Kurt Dreifuss und Geschwister." The five Dreifuss children were: Kurt (1898-1946), Paul (1902-?), Ilse (1908-?), Egon (1910-?), and Friedrich (1912-?) $)^{4}$.

Josef, the father, was born in Dürrheim, and Rosa, the mother, in Hockenheim. In Offenburg, the Dreifuss family ran a furniture business. After Rosa's death, the younger children were sent to Dürrheim, and Kurt returned to Frankfurt, to a business apprenticeship. All too soon, he was a soldier on the Western Front, where death "was no longer a surprise, but a shock" (Offenburg 1945b:16).

Years later, Kurt, who by now had established himself as the writer Kurt Offenburg, reminisced on the early years of the twentieth century, "damals, noch tief in Friedenszeiten," as he put it: those times still deep in peace. The occasion was a tribute to the poet and publisher Ernst Preczang (1870-1949), on his sixtieth birthday:

Lieber Ernst Preczang; bald wird es ein Vierteljahrhundert her sein, seit ich die ersten Gedichte von Ihnen las; damals zu Hause im »Volksfreund « und, wenn ich mich nicht irre, auch in der »Gleichheit«. Diese Verse - ich erinnere mich noch, als wäre es gestern gewesen - waren so stark und einfach im Rhythmus, dass sie dem Knaben immer im Ohr sangen. Durch viele Schulstunden, wohin sie nicht gehörten; durch viele Tage bei den einsam melancholischen Spaziergängen am rauschenden Fluss (über wieviele Wehre brauste er schäumend, alte grün unmooste Mühlräder treibend)! Die Inhalte der Gedichte, das Bekenntnis zum Sozialismus und zur Solidarität, gruben sich selbstverständlich wie Volkslieder in die Seele des jungen Lesers. (Offenburg 1930)

Dear Ernst Preczang, soon it will be a quarter of a century since I first read poems by you. It was long ago, at home, in periodicals like the Volksfreund and, if I am not mistaken, in Gleichheit. These works - and I remember as though it had been yesterday - were so 
strong and simple in rhythm that they could forever sing within a child's ear. During many a school hour, where they did not belong, and on many a solitary, melancholic walk along the rushing stream (over how many weirs had it swirled and foamed, turning old green mossy mill wheels)! The contents of the poems, the calling to socialism and solidarity, penetrated the soul of the young reader as readily as did folksongs. (My translation)

Some two years after writing this tribute, Offenburg was again reminiscing on the landscapes of his childhood. It was April 1932, in the interior of China, on a steamer heading down the Yangtze River; Offenburg was "the only white man among two score of well-to-do Chinese merchants and high Civil servants, some with and some without their concubines." After four days, with another three before they would reach Shanghai, a nun boarded the crowded steamer. Offenburg overheard her speaking Mandarin with two Chinese men and noticed occasional English expressions. When he heard the words "Black Forest," his curiosity was aroused. He approached her and it was then established that both she and he had been born in that corner of Germany (Offenburg 1945b:181-2):

And at once we began to speak in our native tongue. All afternoon and most of the next day and the next one we talked about the Black Forest, that most southern part towards the Swiss border with its dense and dark pines, its great snow-covered mountains, its low thatched houses and the old villages, where women wear white hats made of clay, decorated with big red balls, and where the girls have their names and birthplaces stitched on the collars of their Sunday frocks.

The nun had arrived in China in 1910, at the age of nineteen, and worked the whole time in the interior. She had never been back to Europe, not even to a Chinese coastal city. As the steamer approached Shanghai she contemplated the city and confided her fears of cities to Offenburg. She would be travelling to Europe, accompanying a nun who could not travel alone, and undertook to send Offenburg a postcard from the Black Forest. Three days later she set sail on the Georges Philippar, a French liner (Anon. 1931) returning to Marseilles on its maiden voyage to the Far East. A 
fortnight later, on 16 May, disaster struck near Cape Guardafui, in the Gulf of Aden. Fire broke out and, on 19 May, the Georges Philippar sank; fifty-four persons perished (Hocking 269), including Offenburg's nun.

Offenburg recorded a quiet tribute to her in an article, "The Black Wing" (1945b:179-185). The nun's name is not given, but her appearance and personality come through with a gentle dignity. "Jeder einzelne Mensch eine Welt!" Offenburg had written a few years earlier (1928a:1678), when he contemplated the names of British and American soldiers killed on the Western Front in the First World War. It applies here too: every single person a world!

\section{My successor, however, was not a Communist}

Agnes Smedley (1892-1950) - described by her most recent biographer as "one of the most significant American women of the twentieth century" - was special correspondent in China for the Frankfurter Zeitung from late 1928 until late 1931. She was, this biographer noted, "a flamboyant journalist, feminist, and political activist who made historic contributions to letters and politics on three continents", and "not the first revolutionary to operate in Asia under the cover of the Frankfurter Zeitung" (Price 2005a:2,167).

There have so far been two Smedley biographies. The authors of the first biography began by stating that "even the most ordinary facts about her life, including her birthdate, were a mystery" (MacKinnon and MacKinnon ix). But, wrote the second biographer, the first biographers had dismissed "in a single sentence" the charge that Smedley "worked for the Comintern" (Price 2005b). The second biography came seventeen years later and used words by the American journalist and abolitionist leader, William Lloyd Garrison (1805-1879), as an epigraph: "I will be as harsh as truth, and as uncompromising as justice."

Offenburg came into the Smedley frame, as described by Smedley herself, in the following way (1935:9-10):

During the Japanese invasion a correspondent for the Frankfurter 
Zeitung arrived in Shanghai to take my place, after the Nanking government, working through the German Foreign Office, had demanded my dismissal from the newspaper. I had refused to become an "adviser" to the department in Nanking - which meant keeping my mouth shut - and of course this proved definitely that I was a Communist. My successor, however, was not a Communist; so immediately upon arrival he dashed off to the Chinese mayor of greater Shanghai and asked for money to carry on in style. Someone blabbed, the news was cabled to Europe, and the impatient gentleman was recalled. Had he waited a week, the Chinese would perhaps have made him an "adviser" to some department in Nanking or the Japanese would have stalked into his room and plunked down a bag of yen.

Smedley did not name Offenburg here, but nevertheless aimed several barbs in his direction. Eight years later, when she again described her parting with the Frankfurter Zeitung, "after mutual expressions of regret," she included an ingenious barb when she wrote: "A German, later one of Hitler's propagandists, was mentioned as my successor" (1943:110).

Offenburg sent his version of what had happened to Germany (1932b), with corroboration by Wu Te-chen (1888-1953), an old associate of Sun Yat-sen. Wu, described as "a delightful gentleman" (Abend 136), was Mayor of Greater Shanghai, where "he had gained an enviable reputation for honesty and competence" (Utley 23), and "whose enlightened administration made that city famous" (Mowrer 40). Offenburg stated that he had sought advice from Wu on the possibility of a discount rate for sending cables of between 800 and 1,200 words from Shanghai, instead of resorting to the more than three weeks delay for longer reports sent to Germany via the TransSiberian Railway ${ }^{5}$. A subsequent report from the Russian news agency, TASS, claimed that Offenburg had begged for money from Chinese authorities, as the Frankfurter Zeitung was in financial difficulty and that, as a return favour, the Frankfurter Zeitung would adopt a China-friendly stance. Offenburg insisted that this was an "absolute lie" (1932b). He believed that Smedley was behind the fabrication and had used Russian connections to spread it. When Wu realized what was happening, he wrote to Offenburg (1932):

I am glad to take the opportunity to testify that so far as my 
knowledge serves me, you approached me only on one occasion to ascertain whether, in view of the necessity of sending long reports to Germany in order to cover the international situation here in this city, it was possible to secure special cable rates for your paper. You may quote me as saying that I have never been approached by you with any request for financial assistance or any similar proposal for financial aid.

To suggest that Offenburg might have become an advisor in Nanking is as unfair as it is to hint that it was perhaps Offenburg who was "later one of Hitler's propagandists". Smedley's friend, Freda Utley (1898-1978), has mentioned "the exaggerated accusations she hurled at her adversaries", but insisted that, despite this, "Agnes Smedley was the most honest of women, aware even of her own weaknesses" (Utley 216). It is sad that circumstances had turned Smedley and Offenburg into adversaries. Offenburg, after all, as the Australian historian Charles Bean (1879-1968), subsequently wrote, was a person who "hated hypocrisy, social, national or international; and the opportunity for free, direct, sincere public speech and writing was the breath of his existence" (1946a).

In China, Offenburg had interviewed many prominent figures, including Wang Ching-wei (1883-1944), who at that time headed Chiang Kai-shek's government in Nanking; he had also read a copy of Wang's book, China and the Nations, which Wang had given him ${ }^{6}$. Offenburg summed Wang up as "an ambitious self-seeker" (1940). Regarding the Japanese, Offenburg referred to them as "the Prussians of the East" (1942b). In Germany he had spoken against Nazism and, as a consequence, his life was threatened (Anon. 1946b); while still in Shanghai, he heard that his flat in Frankfurt had been ransacked by Nazis and his library burned (Petersen 138). Or did this occur later, and could Offenburg have been in Europe in 1933, as suggested in a subsequent essay on Paris, where he began by stating that he was "nearly thirty-five" (1938a:12) when he was last there and, later in the same essay, wrote: "I was thirty-five when I sat for the last time in the Luxembourg Gardens after returning from a journey round the world and about to be off on another one" (1938a:85) ${ }^{7}$ ? 
The German Consul-General in Hankou, Wilhelm Timann (18821961), had complained to Berlin in November 1931 about a specific article by Agnes Smedley in the Frankfurter Zeitung (Smedley 1931), and asked that the Frankfurter Zeitung be informed; the article, he wrote, was one-sided, superficial and harmful to German interests (Timann 1931). At almost the same time, the German Consul-General in Shanghai, Heinrich Freiherr Rüdt von CollenbergBödigheim (1875-1954), added to an earlier complaint regarding articles by Agnes Smedley, and now included a letter he had received from Huang Petzian, a Chinese engineer who had been educated in Germany (Rüdt 1931). Huang asked that the Frankfurter Zeitung should cease publishing articles by Agnes Smedley. Within the same month, the Frankfurter Zeitung wrote to inform the Foreign Office in Berlin that Kurt Offenburg would be sent to China, and possibly Japan, as the newspaper's special correspondent (VFZ 1931). It seems that this was a move to minimize the need to seek further articles for the Frankfurter Zeitung from Smedley (Crull 1932a), although there were in fact subsequent articles by her (for example, Smedley 1932). Her employment with the Frankfurter Zeitung ceased in December 1931 and she was then described as a freelance journalist (DGP 1932).

It is true that the Frankfurter Zeitung was in financial difficulties, and also that it had succumbed to "the growing ideological crisis which pervaded German liberalism in the second half of the 1920s" (Eksteins 1975:160). It is also apparent that German officials were not helpful towards Offenburg when the TASS report came out; the Consul-General in Shanghai apparently found the Russian report credible and considered a consular protest to be incorrect (Rüdt 1932). Later that year, when the Foreign Office in Berlin noticed that articles by Offenburg were appearing in the Frankfurter Zeitung from Tokyo, the German Embassy in Tokyo was sent details of what had happened to Offenburg in Shanghai, so that officials there could judge Offenburg's personality and be forewarned (Crull 1932b).

It was Australia's great gain when Offenburg chose to settle there. The choice, he later wrote, was "between accepting a social philosophy which identifies God with the State, and as an end in 
itself: or choosing a community which upholds individualism, humanism and reason" (Offenburg 1938b). Or, as Charles Bean put it (Bean 1946b):

He became an Australian because he could not live in a country in which speech, writing and discussion were throttled. His high education and keen insight convinced him that certain truths, as he conceived them to be, were vital to the security and happiness of his fellow man; and he could not live unless he could speak his mind freely. In Australia he found ample and constant opportunity for this, and that was a main cause of his adoption of our citizenship, and his satisfaction in his life here.

Offenburg died far too soon, in May 1946, at the age of forty-seven.

\section{Acknowledgements}

Many people have helped me in my "Herr O." search since its beginnings in 2004. Here I would like to thank in particular: Simeon Barlow, John Barnes, Regina Brischle, Judith Hamilton, Irmgard Heidler, Gernot Kreutz, Martin Kröger, Anna Lanyon, John Levi, Andris Liepens, Humphrey McQueen, George Matoulas, John Moses, Mew Leng Mouy, Richard Overell, Hanneliese Palm, Monica Raszewski, Sebastian Salt, Dennis Spiteri, Guy Tranter and Heidi Zogbaum. The article is dedicated to composer George Dreyfus on the occasion of his 80th birthday (22 July 2008). I thank him for an unflagging interest in this other Australian "Herr Dreifuss."

\section{Abbreviations}

BRFZ Berliner Redaktion der Frankfurter Zeitung

DGP Deutsche Gesandschaft Peping (the name 'Peping' was adopted by the Kuomintang in 1928 and used until 1949).

DJNI Deutsches Jahrbuch für Niederländisch-Indien

NAA National Archives of Australia

PAAA Politisches Archiv des Auswärtigen Amts

VFZ Verlag der Frankfurter Zeitung

\section{References}

Abend, Hallett, 1944. My years in China, 1926-1941. London: John Lane, The Bodley Head.

Anon., 1930. "Interesting Visitors at 'The Australia': Mr. Kurt Offenburg".

The Australia Handbook, 6(3), 17.

Anon., 1931. "Motor Passenger Liner 'Georges Philippar'". Shipbuilding 
and Shipping Record, 38(27), 832-837.

Anon., 1932. "Personal". Sydney Morning Herald, 12 November, 12.

Anon., 1946a. "Kurt Offenburg's Death". Sydney Morning Herald, 17 May, 4.

Anon., 1946b. "Will miss forthright voice of Offenburg". The ABC Weekly, 1 June, 40.

Bean, Charles E W, 1946a. "Dr. Bean's Tribute". Sydney Morning Herald, 17 May, 4.

Bean, Charles E W, 1946b 23 May: "Broadcast Commentary". 2FC, 1.15 pm, transcript. NAA, SP300/1, Box 25.

Berliner Redaktion der Frankfurter Zeitung, 19322 April: Letter to

Herrn Botschaftsrat Dr. Freiherr von Schoen, German Foreign Office. PAAA, R 121887.

Bonnell, Andrew G, 2000. "Stephen Roberts' The House That Hitler Built as a Source on Nazi Germany". Australian Journal of Politics and History, 46(1), 1-20.

Crull, Wilhelm, 1932a 16 February: "An die Deutsche Gesandtschaft Peping". PAAA, R 121887.

Crull, Wilhelm, 1932b 17 June: "An die Deutsche Botschaft Tokio". PAAA, R 121887.

Deutsche Gesandschaft, Peping, 19322 February: "Deutsche Pressevertreter in China". PAAA, R 121887.

Deutsches Jahrbuch für Niederländisch-Indien, 1930. Batavia: G. Kolff \& Co.

Eksteins, Modris, 1971. "The Frankfurter Zeitung: Mirror of Weimar Democracy". Journal of Contemporary History, 6(4), 3-28.

Eksteins, Modris, 1975. The Limits of Reason: The German Democratic Press and the Collapse of Weimar Democracy. London: Oxford University Press.

Elkin, A P, 1941. Our Opinions and the National Effort. Sydney: Australasian Medical Publishing.

Hocking, Charles, 1969. Dictionary of Disasters at Sea During the Age of Steam, including Sailing Ships and Ships of War Lost in Action, 18241862, vol.1, A -L. London: Lloyd's Register of Shipping.

Kessler, Friedrich von, 193013 September: Letter to Herr von Kaufmann, German Foreign Office. PAAA, R 121871.

MacKinnon, Janice R, and MacKinnon, Stephen R, 1988. Agnes Smedley:

The Life and Times of an American Radical. London: Virago.

Marks, Gladys H, 194027 May: Letter to the Manager, News Dept., Australian Broadcasting Commission. NAA: SP286/6, Box 2.

Mowrer, Edgar Ansel, 1938. Mowrer in China. Harmondsworth: Penguin. 
Offenburg, Kurt, 1921. "Intellektuelle und Proletariat". Die Aktion, $11(27 / 28), 376,379$.

Offenburg, Kurt, 192414 November: Letter to Armin Wegner. Deutsches Literaturarchiv Marbach, HS001678388.

Offenburg, Kurt, 1925a. 11/10: Ein zeitgenössischer Roman. Frankfurt/Main: Mittelland.

Offenburg, Kurt, 1925b. Arbeiterdichtung der Gegenwart. Frankfurt/Main, Mittelland.

Offenburg, Kurt, 1925c. "Gespräch um Mitternacht". Sozialistische Monatshefte, 31(9) 561-562.

Offenburg, Kurt, 1928a. "Nach zehn Jahren". Deutsche Republik, 2(2), 1671-1678.

Offenburg, Kurt, 1928b. "Rüstkammer des Todes". Frankfurter Zeitung, 2 August.

Offenburg, Kurt, 1930. "Bekenntnis zu einem Arbeiterdichter: Ernst Preczang zum 60. Geburtstage". Vorwärts, 16 January.

Offenburg, Kurt, 1932a. "Boykott: Chinas tödliche Waffe". Frankfurter Zeitung, 13 March, 3.

Offenburg, Kurt, 1932b 16 April: Letter to Herr Jantschge, Frankfurter Zeitung, Frankfurt/Main. PAAA, R 121887.

Offenburg, Kurt, 1934. These Glorious Crusaders: A Contemporary Novel, translated by the late C. J. Brennan. Sydney: Macquarie Head.

Offenburg, Kurt, 193616 October: Statutory Declaration by Kurt Dreifus Offenburg. NAA, A1 1936/11104. (In Australian documents, Offenburg spelled "Dreifuss" with a single " $s$ " to give "Dreifus.")

Offenburg, Kurt, 1938a. "Paris: A Revelation". The BP Magazine, Winter Number, 1 June, 12-13, 85-86.

Offenburg, Kurt, 1938b. "Civis Britannicus sum". Sydney Morning Herald, 30 July, 13.

Offenburg, Kurt, 19404 December: "The Puppet Government of Nanking". 2FC, 7.15 pm, transcript. NAA, SP369/2, Box 2.

Offenburg, Kurt, 1941. War in the Pacific? Sydney: Gayle.

Offenburg, Kurt, 1942a 30 January: "News commentary". 2FC, 7.23 pm, transcript. NAA, SP369/2, Box 2. (The last page was not broadcast.)

Offenburg, Kurt, 1942b 7 July: "News Commentary". 2FC, 7.23 pm, transcript. NAA, SP369/2, Box 2.

Offenburg, Kurt, 1942c 20 July: Letter to Nettie Palmer. National Library of Australia, MS 11174.

Offenburg, Kurt, 1945a 6 July: "War Diary". 2GB, 10.15 pm, transcript. John Curtin Prime Ministerial Library, JCPML00401/55.

Offenburg, Kurt, 1945b. World in Dust: A Personal Record. Sydney: Gayle. 
Petersen, Neville, 1993. News Not Views: The ABC, the Press, \& Politics, 1932-1947. Sydney: Hale \& Iremonger.

Plowman, Peter, 1992. Emigrant Ships to Luxury Liners: Ships to Australia and New Zealand, 1945-1990. Kensington: New South Wales University Press.

Price, Ruth, 2005a. The Lives of Agnes Smedley. Oxford: Oxford University Press.

Price, Ruth, 2005b. "Agnes Smedley, and Example to Whose Cause?" Chronicle of Higher Education, 29 July, B9-B10.

Ramsland, John, 2006. "Images of Sophisticated Cosmopolitanism: The Australia Hotel, Sydney, 1891-1970". Australiana, 28(1), 20-28.

Rüdt von Collenberg-Bödigheim, Heinrich Freiherr, 193110 November: "Mrs. Agnes Smedley als Korrespondentin der 'Frankfurter Zeitung'". PAAA, R121887.

Rüdt von Collenberg-Bödigheim, Heinrich Freiherr, 19321 April: Telegram to the German Foreign Office. PAAA, R 121887.

Smedley, Agnes, 1931. "Der Tod in China: Hungersnot, Ueberschwemmung, Krieg und die 'Justiz'". Frankfurter Zeitung, 8 October.

Smedley, Agnes, 1932. "Die Philippinen sind ein armes Volk". Frankfurter Zeitung, 5 June, 1.

Smedley, Agnes, 1935. "The Corrupt Press in China". The Nation, 141(3652), 8-10.

Smedley, Agnes, 1943. Battle Hymn of China. New York, Alfred A. Knopf. Struve, Walter, 2004. "Who was Kurt Offenburg?" ISAA Review, 3(2), 613.

Struve, Walter, 2006a. "'Dedicated to the Promotion of International Understanding': A Memorial for Kurt Offenburg at the State Library". La Trobe Journal, 78(Spring), 56-70.

Struve, Walter, 2006b. "Lynkeus the Watchman in Australia". ISAA Review, 5(2), 39-45.

Timann, Wilhelm, 193112 November: "Tendenziöse Berichterstattung der 'Frankfurter Zeitung'". PAAA, R 121887.

Utley, Freda, 1939. China at War. London: Faber and Faber.

Verlag der Frankfurter Zeitung, 193128 November: Letter to the German Foreign Office. PAAA, R 121861.

Wu Te-chen, 193216 April: Letter to Mr. Kurt Offenburg, Frankfurter Zeitung, Shanghai. PAAA, R 121887. 